(C) Inra/Elsevier, Paris

Letter to the editor

\title{
Revised COGNOSAG guidelines for gene nomenclature in ruminants 19981
}

\author{
Thomas E. Broad ${ }^{\text {a }}$, Charles H.S. Dolling ${ }^{b}$, \\ Jean-Jacques Lauvergne ${ }^{c *}$, Paul Millar ${ }^{d}$ \\ a AgResearch, P.B. 50034, Mosgiel, New Zealand \\ ${ }^{\mathrm{b}}$ Box 74, McLaren Vale, South Australia \\ ${ }^{c}$ Laboratoire de Génétique factorielle, bât. 211, CRJ/Inra, \\ 78352 Jouy-en-Josas cedex, France \\ d 12A Riselaw Crescent, Edinburgh, Scotland EH10 6HL, UK
}

(Received 14 January 1999)

\begin{abstract}
The 1993 guidelines proposed by COGNOSAG were designed to accommodate the naming of loci, including mapped and cloned loci in all ruminants, and to facilitate the development of a genome nomenclature consistent as far as possible between ruminant species. The guidelines have been revised, and COGNOSAG recommends that they be adopted not only for the ruminants sheep, cattle and goats but also for other farmed animals, such as pigs, horses, deer and camelids. (C) Inra/Elsevier, Paris
\end{abstract}

ruminants / genes / nomenclature

Résumé - Règles de nomenclature du COGOVICA pour les gènes des ruminants, révisées pour 1998. Les règles de nomenclature proposées en 1993 concernaient tous les gènes et loci cartographiés et clonés des ruminants. Le but était de faciliter l'élaboration d'une nomenclature rationnelle du génome de ces espèces. Dans le présent article ces règles ont été révisées et le COGOVICA recommande qu'elles soient étendues non seulement aux ruminants comme le mouton, la chèvre et le bœuf mais aussi à d'autres animaux de ferme comme le porc, le cheval, le cerf et les camélidés. (C) Inra/Elsevier, Paris

ruminants / gènes / nomenclature

* Correspondence and reprints

E-mail: ugenjjl@dga2.jouy.inra.fr

1 The revised guidelines were endorsed by the 13th COGNOSAG Workshop at Lednice, Czech Republic in July 1998. 


\section{INTRODUCTION}

The guidelines from the 1998 Workshop, held at the Mendel University of Agriculture and Forestry Brno, Lednice, Czech Republic, are based on earlier proposals from COGNOSAG Workshops at Gontard/Manosque, France, July 1986 [5] and July 1987 [1], at Eugene, Oregon, June 1989 [2], at Gontard/Manosque, July 1991 [3], and at the Turretfield Research Centre, Rosedale, South Australia, 1993 [4].

The core of these revised guidelines consists of the 1991 proposals [3]. Their re-wording has been undertaken to reduce their length, and to increase their clarity. The earlier recommendations to limit the length of symbols of loci and alleles to a maximum of five and four characters, respectively, have been relaxed. The designation of top dominant and co-dominant alleles by a capital initial letter has been undertaken to assist in the recognition of alleles with visible effects. Thus, the changes made are intended to render the guidelines more permissive and user-friendly, while retaining consistency with the human and mouse systems of nomenclature. Our recommendations include the use of species prefixes, for example, $O O V$ or $O A R$ for sheep, $B T A$ or $B B O$ for cattle, and the adoption of the nomenclature for keratins and keratinassociated proteins proposed by Powell and Rogers [6]. An additional proposal for provisionally assigning symbols and listing newly reported DNA segments and proteins that have no known homologues, official names or symbols is also outlined.

COGNOSAG will respect as far as possible the names of loci and alleles proposed by authors and will propose new names only in the light of new knowledge or to maintain consistency with the existing nomenclature.

The use of names and symbols in italics for loci and their alleles is preferred. However, if it is not possible to comply with this, then those names and symbols will be underlined. Authors are asked to be consistent in the underlining or use of italics for the names and symbols within a document and/or file. Locus and allele symbols need not be in italics or underlined in databases, but should be in italics in hardcopy from these databases.

\section{LOCUS}

\subsection{Locus name}

\subsubsection{Choice of name}

The name in English should be as brief as possible but not consist of a single letter, and should convey as accurately as possible the character affected or the function by which the locus is recognised. The name may indicate a morphological character (Ear Length) or disease character (Photosensivity), a body system or body function (Fecondity Java), or a biochemical property (Albumin) or nucleotide segment (DNA Segment: probe MAF4). As far as possible the locus name should reflect interspecies homology.

All Greek symbols should be written in full in Latin letters and placed after the name, e.g. $\beta$ Haemoglobin becomes Haemoglobin Beta. 
If a newly described locus has an effect similar to one that has already been named, then it may be named according to the breed, geographic location or population of origin.

\subsubsection{Printing the name}

The locus name should be written in Latin letters or in a combination of Latin letters and Arabic numerals. Wherever possible, the locus name should be printed in italics; otherwise it should be underlined.

The initial letter of the locus name should be a capital Latin letter.

Both nouns and adjectives in locus names should begin with capital Latin letters, e.g. Ear Length, Haemoglobin Beta: Ear Length, Haemoglobin Beta: Ear Length, Haemoglobin Beta.

\subsection{Locus symbol}

\subsubsection{Choice of symbol}

For newly reported loci, unmapped DNA segments and proteins which have no known homologues or official names or symbols, special care should be exercised in selecting an appropriate symbol to avoid duplication and confusion with existing nomenclature (see section 2). Every effort should be made to ensure that the symbols selected conform to those in current use for homologous loci.

The locus symbol should consist of as few Latin letters as possible, or a combination of Latin letters and Arabic numerals.

The initial character should always be a capital Latin letter which, if possible, should be the initial letter of the name of the locus.

For loci other than those for coat colour and visible traits, upper-case Latin letters only, or upper-case letters combined with Arabic numerals, should be used.

If the locus name is of two or more words and the initial letters are used in the locus symbol, then the letters should be in Latin capitals.

All characters in a locus symbol should be written on the same line; no superscripts or subscripts, and no Roman numerals or Greek letters should be used. Where appropriate, the symbol should indicate the biochemical property or designate a particular nucleotide segment.

The rules of mammalian inter-specific homology already used in the choice of the name of the locus should be applied to the choice of the symbol.

The designation of prefixes denoting mammalian species of origin, when being used to distinguish between the species homologues of a locus, should follow either that recommended by The Human Genome Nomenclature Committee, e.g. $O O V$ or $O A R$ for sheep, $B T A$ or $B B O$ for cattle, $C H I$ for goat, $S S C$ for pig and $E C A$ for horse. COGNOSAG recommends that each author be consistent in the use of whichever symbol has been chosen. For the keratins and keratin-associated proteins, COGNOSAG recommends that authors adopt the symbols and names proposed by Powell and Rogers [6]. 


\subsubsection{Printing the symbol}

Wherever possible the locus symbol should be in italics; otherwise it should be underlined, e.g. the symbol of the Agouti locus: $A$ or $\underline{\mathrm{A}}$.

\section{ALLELES}

\subsection{Allele name}

\subsubsection{Choice of name}

The name should be as brief as possible, but should convey the variation associated with the allele. If not given names, alleles should be given symbols as described in section 3.2 below. If a newly described allele is similar to one that is already named, it should be named according to the breed, geographic location or population of origin. The names of new alleles at a recognised locus should conform to the nomenclature established for that locus. Should a new allele be identified later as being the same as an allele already named, the name invoking breed, geographic location or population of origin should be abandoned.

\subsubsection{Printing the name}

Wherever possible, the allele name should be in italics; otherwise it should be underlined. A lower-case initial letter of the allele name is preferred. This does not apply when a symbol is used instead of an allele name. For example, the allele for the polled condition at the Horns locus in sheep: polled or polled; an allele at the Haemoglobin Beta locus: B or $\underline{\mathrm{B}}$.

\subsection{Allele symbol}

\subsubsection{Choice of symbol}

The allele symbol should be as brief as possible, consisting of Latin letters and/or Arabic numerals.

As far as possible, the allele symbol should be an abbreviation of the allele name, and should start with the same letter. In the loci detected by biochemical, serological or nucleotide methods, the allele name and symbol may be identical.

Greek letters and Roman numerals should not be used.

The symbol ' + ' can be used alone for identification of the standard allele ('wild type') for alleles having visible effects. Neither '+' nor '-' symbols should be used in alleles detected by biochemical, serological or nucleotide sequencing methods. Null alleles should be designated by the number zero.

The initial letter of the symbol of the top dominant allele should be a capital letter. When there are co-dominant alleles only, they should each have a capital initial letter. The initial letter of all other alleles should be in lower case. 


\subsubsection{Printing the symbol}

The allele symbol should always be written with the locus symbol. It may be written as a superscript following the locus symbol, or following an asterisk on the same line as the locus symbol. The allele symbol should be printed immediately adjacent to the locus symbol, i.e. with no gap between them.

Wherever possible, the allele symbol should be in italics; otherwise it should be underlined. For example, the recessive allele hornless at the Horns locus in sheep will be printed in italics: $H o^{h l}$ or $H o^{* h l}$ or underlined $\mathrm{Ho}^{\text {hl }}$ or $\mathrm{Ho}^{* \mathrm{hl}}$. The dominant allele polled will have the symbol in italics, $H o^{\bar{P} \text { or }} H o^{* P}$, or underlined, $\underline{\mathrm{Ho}^{\mathrm{P}}}$ or $\underline{\mathrm{Ho}^{* \mathrm{P}}}$.

\section{GENOTYPE TERMINOLOGY}

The genotype of an individual should be shown by printing the relevant locus and allele symbols for the two homologous chromosomes concerned, separated by a slash, e.g. $\mathrm{Ho}^{P} / \mathrm{Ho}^{P}$ or $\mathrm{Ho}^{\mathrm{P}} / \mathrm{Ho}^{\mathrm{P}}$.

Unlinked loci should be separated by semicolons.

Linked or syntenic loci should be separated by a space and listed in alphabetical order when gene order and/or phase are not known.

In writing genotypes for $\mathrm{X}$-linked loci, the hemizygous case (as in the male) should be designated by $/ Y$ following the locus and allele symbols, e.g. $F e c X^{*} I / Y$ for the inverdale allele of the Fecundity $X$ locus on the $\mathrm{X}$ chromosome in sheep.

In writing genotypes $\mathrm{Y}$-linked loci should be designated by / $\mathrm{X}$ following the locus and allele symbols.

\section{PHENOTYPE TERMINOLOGY}

The phenotype symbol should be in the same characters as the locus and allele symbols. The difference is that the characters should not be in italics, should not be underlined and should be written with a space between locus characters and allele characters instead of with an asterisk. Square brackets [ ] may also be used. For example, the dominant genotype $\mathrm{Ho}^{\mathrm{P}} / \mathrm{Ho}^{+}$is equivalent to the phenotype $\mathrm{Ho}^{\mathrm{P}}$ or $\left[\mathrm{Ho}^{\mathrm{P}}\right]$

\section{ACKNOWLEDGEMENTS}

The authors have presented these guidelines on behalf of all of those members of COGNOSAG who attended the 13 th workshop since the organisation was founded in 1984. They gratefully acknowledge the complementary efforts of members around the world and the support of their host institutions which has made these efforts possible. 


\section{REFERENCES}

[1] COGNOSAG (Alexieva S.A., Denis B., Dolling C.H.S., Lauvergne J.J., Lundie R.S., Millar P., Rae A.L., Renieri C., Sponenberg D.P., Tucker E.M.), Proposed guidelines for gene nomenclature in sheep and goats 1987, in: Lauvergne J.J. (Ed.), Standardized Genetic Nomenclature for Sheep and Goats 1987. Loci for Visible Traits other than Colour and Blood and Milk Polymorphisms, Proc. COGNOSAG Workshop 1987, Gontard, Manosque, Bureau des ressources génétiques, Paris, 1989, pp. 17-21.

[2] CognOSAG (Alexieva S.A., Aliev G.A., Bourzat D., Denis B., Dolling C.H.S., Lauvergne J.J., Lundie R.S., Malher X., Millar P., Rachkovsky M.L., Rae A.L., Renieri C., Sponenberg D.P., Tucker E.M.), Gene nomenclature in sheep and goats 1989, in: Lauvergne J.J. (Ed.), Loci for Coat Colour of Sheep and Goats 1989, COGNOSAG Clamart, 1990, pp. 3-7.

[3] COGNOSAG (Andresen E., Broad T.E., Di Stasio L., Dolling C.H.S., Hill D., Huston K., Larsen B., Lauvergne J.J., Levéziel H., Malher X., Millar P., Rae A.L., Renieri C., Tucker E.M.), Guidelines for gene nomenclature in ruminants, 1991, Genet. Sel. Evol. 23 (1991) 461-466.

[4] Cognosag (Andresen E., Broad T.E., Brown S., Cooper D.W., Di Stasio L., Dolling C.H.S., Fleet M., Hill D.F., Lauvergne J.J., Lundie R.S, Maddox J., Nicholas F.W., Rae A.L., Renieri C., Sponenberg D.P., Tucker E.M.), Revised guidelines for gene nomenclature in ruminants 1993, Genet. Sel. Evol. 27 (1995) 89-93.

[5] COGNOSAG Workshop 1986, Proposed rules for genic nomenclature in sheep and goats, in: Lauvergne J.J. (Ed.), Standardized Genetic Nomenclature for Sheep and Goats, 1986, Proc. COGNOSAG Workshop, Gontard/Manosque, July 1986, Bureau des ressources génétiques and Lavoisier, Paris, 1988, pp. 89-92.

[6] Powell B.C., Rogers G.E., Differentiation in hard keratin tissues, hair and related structures, in: Leigh I., Watt F., Lane E.B. (Eds), Keratinocyte Handbook, Cambridge University Press, Cambridge, UK, 1993. 